\title{
講 座
}

\section{食 物 の 配 色}

\author{
商 宮 和 彦
}

(共立女子大学)

\section{1. 日本人の色彩感覚と食文化の歴史}

日本人は舌先が繊細で味覚の優れた国民であるとよく いわれる，また平安時代の十二単の衣装や，色とりどり の和紙を薄くすいて重ねた色紙の繊細さを見ると, 日本 人は色彩感覚にも優れた民族であると思う。しかしこと 食物の配色についても繊細な感覚の持ち主であったかと いうと疑わしい.

\section{（1）奈良・平安時代}

服飾に抢ける色彩の歴史を展望すると, 華やかな変遷 が記録されている1) 青丹に良しとらたわれた奈良時代に は, 推古天皇11年（603）制定の十二階の位の冠は, 紫, 青, 赤, 黄, 白, 黒の 5 色で, 孝德天皇 3 年 (647) の 朝服の制では位により深紫, 浅紫と真緋, 紺, 緑, 黒, 天武天皇14年（685）にはると食物の名前が一部登場し て尔華色, 深紫, 浅紫と深葡萄, 浅葡萄, 同じく天武天 皇大宝元年（701）の衣服令制では皇太子は黄丹，親王 は深紫, 無位の一般人は黄色, 奴婢は黒褐色, 紺黑から 黒色と目まぐるしく変化している.

また次の平安時代の衣袍も一位が深紫, 二位と三位が 浅葱，四位が深緋と誠に色彩鮮やかである. もっとも次 の鎌倉・室町時代は一転して濃紺から暗色好又の時代に なる。

福田邦夫氏による主な伝統色の分類 ${ }^{2)}$ を見ても桜色, 暲色, 撫子色, 桃花色, 紅梅色, 紅色, 蘇枋色, 茜色, 臙脂色, 肌色, 柑子色, 蒲色, 琥珀色, 第色, 检皮色, 䃄の粉色, 鳥の子色, 支子色, 山吹色, 枯草色, 若芽 色, 若苗色, 萌苟色, 若草色, 柳葉色, 苔色, 山鳩色, 青磁色, 若竹色, 緑青, 松葉色, 宋賊色, 空色, 花色, 月草色, 露草色, 瑠璃色, 群青色, 鉄色, 藤 紫, 桔梗 色, 竜胆色, 杜若色, 菖蒲色, 古代紫, 兏汁色, 鉛色, 墨色などの 127 色が記載されていて, 古代の日本人が優 れた色彩感覚の持ち主であったことが伺われる. しかし
諸外国一般に見られる赤橙黄緑青藍紫の 7 色に基づく名 称とは異なり, 日本の伝統色には枯葉色, 朽葉色, 鶯色 などのように物の名称をとのま色名とする例が多い。 極端に言えば物の数ほど色名があることになり，物質自 体の認識が色自体の認識に先行しているょうに思われ る.

さて上記の 127 種の伝統色の中で, 食物由来の色は小 豆色, 柿色, 栗 (皮) 色, 卵色, 茄子色, 蓄萄色, 叠の 実色，梅紫の八色で，古代色名全体の $6 \%$ 強に過ぎな い. 昭和63年 9 月平城宮の長屋王 (729年没) 屋敷跡出 土の木簡 3 万点から見た当時の貴族の食事が, 美濃の 米, 伊豆からの鰹, 志摩の市わびなどを味噌, 塩, 䇶の だし汁で昧付けして, 酒には遠方の氷室から運ばせた天 然氷を浮かせていたなどと聞くと, 少なくとも貴族の生 活は豊富な食品材料に恵まれていたことが伺われる。し かし色様々に染め付けられた衣裳の華やかな配色に比較 すると, 天然の食物の色に関する関心は一般に低かった と思われる.

布地の染色の歷史を見ると, 中国の周礼や詩経などの 古い文献にみる周王朝では, 五行説に由来する青赤黄白 黒の五色が諸制度に取り入れられていて, 天然色素とし てはアイ, カリヤス, キハダ, クチナシ, ムラサキと赤 色のアカネなどの植物が使用されていたという，漢代の 書物には匈奴の王が燕脂を採取する山を攻め落とされて 「我れ燕支の山を夫い, 我が婦女の顔色なからしむ」と 嘆いているし, 当時は燕脂で顔に彩色したり, 布地を緋 色に染めていたらしい。この燕脂以外に紅藍, 黄藍と呼 ばれた植物は奈良朝以前の雄略期に帰化人に上り日本に 伝えられ, 吳の国を経て渡来した藍といらので筫籃とか 紅籃，さらに開花の早期に刺のある葉先を避けて茎の先 端の花を摘をので末摘花と呼ばれた。この現在の紅花の 渡来は染色の美しさで当時の日本人を驚嘆させたに違い ない, 以来, 日本原産の染色植物の探索が盛んとなり飛 
鳥, 天平の時代に絢爛たる染色工芸が開花したといわれ る. 源氏物語の末摘花の巻もこの帰化植物の名に因んだ ものであろう.

何机にしても平安時代に衣服の染色は進歩し, 紅花も 大いに使用された。醍醐天皇の御代の延喜式（905 年撰 上 927 年完成）は50卷に及ぶ大部なもので, 平安時代の 日常便利帳とい光るが, 907年に当時の日本が諸事の手本 としていた唐が滅亡したので，その直後に撰上された延 喜式には隋や唐の影響が拭色され, 日本独自の法令が集 められている. 当時は全国から薬用や染色用の植物が朝 廷に貢として献上された. 同書巻14の雑染用度には草木 染めが 26 種記載されている．その内の 3 種には紅花が使 用されている。例えば黄丹や浅支子は紅花と支子, 韓紅 篟と退紅は紅花を用いて染められている.

一方, 食物の配色についての記録は少ない. 平安時代 には肥料に使われ，また庶民に好まれて下品とされてい た魺が, 室町時代からはアニより美味なので藍色よりも 濃色の「濃いむらさき」の名で呼ばれるようになったと か，小正月には呪術的な行事があって小豆粥や桜弹を食 した。枕の草子に十五日はもちがゆの節句まいり，土佐 日記に正月十五日は都へ帰る船上のため今日小互张惹 ず, また源氏物語の亥の子餅, 徒然草の䉼餅飯は饀を外 側につけたぼた餅型である，などという僅かな例に食物 の色についての関心を見る程度である。

\section{（2）室町時代から江戸時代}

正式には古典的な日本料理の起源は室町時代の諸家料 理本に始まるといえる. しかし当時の日本料理は口伝に 近いもので，いわゆる五行説を遵守していたと考兄られ る. 1659年以前に刊行された「料理切形秘伝抄（包丁秘 密)」》゙は四条家之秘伝等を紹介しているが，本饗膳には 松は千とせの祝にてお（雄）松を立てる（十ウ）が「八 種のくた物にて五色の心得有へし(十一ウ)」と記され ている. この五色は赤青黄白黒の事で五行説に因んでい る. 五行説は原初の混沌とした天地未文化の中から陰と 陽の二気が生じ，陽は上昇して天となり，日月星辰を生 み，㓌は下降して地になり地上に木火土金水の五気を生 じたとする陰陽五行思想で，五気のそれぞれが木気（青 で春), 金気 (白で秋), 水気 (黒で冬), 火気 (赤で夏), 土気（黄）を指している．三原色飞白黒の明暗を加える 考方方である. 日本料理でもこの五色に浱る活力，つま りは人力の及ば魔王の全身に溢孔る活力で象徵された 食物を食して, 自分達も活力を得たいと考光たのである う.「料理切型秘伝抄, 2 オ $]^{3)}$ や「当流節用料理大全, 七，10才（四条家高島氏撰，1714年刊)」4) の雑著の説明
には「雑惹は魔王の五臟をかたどりしゅくす」とあり， 五行五色を各臟器に，またさらに食物へと関連づけてい る.

\begin{tabular}{|c|c|}
\hline （五臓）（色） & （食物） \\
\hline 心（しん）……火色の赤 & ……鰹（心をかたどる） \\
\hline 肝（かん）……色の青（緑） & $\begin{array}{c}\text { ……芋（眼，瓜をかたどる. } \\
\text { いも丸長く削る) }\end{array}$ \\
\hline 脾（ひ ）…..上色の黄 & ……串鮑（皮肉をかたどる） \\
\hline 肺（はい）……金（か、叔）の白 & ……餅（気に通ずる） \\
\hline 腎（じん）…...水の黑 & $\begin{array}{l}\text { ……乾海鼠（いりこ，耳に通 } \\
\text { ずる） }\end{array}$ \\
\hline
\end{tabular}

他にるこの五色には縁起ものとしての諸説がある. 料 理切形秘伝抄 $(七, 8 \text { オ })^{3)}$ と当流節用料理大全 (十二, 廿, 15オ $)^{5)}$ には, 周の武王が舟に飛び込んた解をしゃく で押さ光, 包丁なされける云々で, この時海中しつかに して五色の波立けり, 是天道にかなひ給ふ, 五色鱛と申 候也，と言うことで五色の姿に盛ったとある. 江戸時代 の日本料理も, こと配色に関してはこの五色の取り合わ せにこだわっていた事は「歌仙の組糸（1748）」5゙ にも伺 われる. しかし同書には料理心得が十四ヶ条も述べられ ているのに, 配色への注意は行われていない.ただ「惣 して取合塩梅盛方心得べき事 まつ取合は青黄赤白黒の 五つを取はつさぬようにして塩梅は五味をふまえ」とあ る位である ${ }^{5}$.

しかし配色を五色と定めても, 色鮮やかな五色の食品 材料がそう揃うものではない。また天然の食物の色には 衣装などとは異なり鮮やかな原色が少ないし，特に赤系 統の色は調理により退色する. そこで十六世紀る後半に なると苦心して着色し五色を揃劣ることになる。「柚珍 秘密箱 (1785)」6) では花柚 30 色くらい出せると称してい るが, 例郎ば「鯛百珍料理秘密箱（1785）」7)では鯛の片 身のままが白, カラメルによる着色で赤, クチナシの汁 で染めて黄, 大根や菜の葉色汁で青, 黒豆色汁と鍋炭と 酒で黒(と言っても浅黄鯛になる),「甘藷百珍 (1789)」」) の五色は紅藍で浅紅, 深紅と好みの赤に, 皇青粉で青, 鍋墨で黒, 紅と青粉で紫色, 諳精で白, 山梔子の汁で黄 色と言う具合に染め分けている。 その他「躾方の事（禁 中及び公家之御箭」の五色なますの白る身そのまま, 赤 はケイトウの葉, 青はカラシの葉, 黄はイ（イクサ）な ぞで染めている.また椿の灰汁に浸し蒸して黄色に仕上 げる朝比奈粽 (南蛮料理書),クチナシで黄色に染めて染 飯, ウコンで染めて香飯, 紅花や生燕脂で染めて紅花食 (名飯部類，18029)）などがある. 何れにしても江戸時 代に和ける配色の苦労が偲ばれる。

しかし江戸時代にも西欧流の色彩論は伝わっていて， 
ニュートンがガラスのプリズムを通して光が 7 色に別れ ることを発表（1666）し，ル・ブロンが赤黄青の基本色 を定めて活ぼ100年後に, 渡辺崋山が弟子の椿椿山に出 した書簡「絵事問答」には，下図のような色系図が記さ れているといら ${ }^{10)}$. 杉田玄白らの「解体新書(1774)」と 同時代である. 当時の日本料理は一つの頂点に達してい て, 黒船来航で驚いた幕府が提督ペリーを饗応した祝膳 は 300 人前, 23 種に達したと言う.

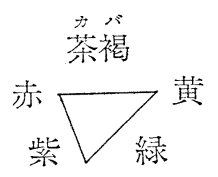

青

\section{（3）明治 · 大正 - 昭和初期}

明治時代に入ると，世は一転して文明開花を謳歌する ようになり, 幕末の戦乱期が一転して明治初期の洋食尊 重の世に変わると, 日本料理の伝統は一時衰退する ${ }^{11}$. 日本料理が再び復活するのは, 華族有志による紅葉館 (明治14年) と三井系の星岡茶寮（明治16年）等の完成, また政界・財界に打ける待合政治によるるので, 日本料 理の料理人が巷から呼び集められ腕をらるうようになっ てからであると云われる。

しかし明治期の色彩教育と民衆の色彩への関心を見る と, 当時は墨絵の流行と色彩への軽視が目立つ. 文部省 が設立されて教科書が編纂されたが, 明治 7 年 8 月改正 の邑図には47色がのせられていて, 日光色, 三原色, 混 色, 最冷色, 最熱色, 進出色, 後退色などが記載され, 解説書も多く出版されたが，この配色論の兆は $4 \sim 5$ 年 で消えてしまう．例えば文部省第四年報第一冊には「色 図八童子二七色ヨリ其他の重立タル色ノ名ヨ教フレバ事 足ルベシ」とか「光学専門/語ヨ教フルヨ以テ童子八其 何如タル 解セズ, 唯教師/口真似スルノミナリ」とあ る.さらに明治10年から起こった国粋論に基づく毛筆画 教育が明治 $23 \sim 24$ 年から次第に鉛筆画を圧迫し，明治 36 年位までが毛筆画の最盛期となる。ようやく明治36年の 高等女学校教授要目に, 自在画棌色 $习$ 施スコトヨ授 クヘシ」とあるが, 黑田清輝が委員の文部省図画教育調 委員査会報告（明治37年）に打いても「水彩を以テ着色 スル八尋常小学校第三学年以上ニ限ルヘシ」といら程度 である. 最も明治 36 年の小学校教師用教科書には, 教材 に示す所の色は青黄赤白黒と名つく, この一列を五色と いいて多くの色の基とするものなりと再び五色の記載が 見られる. 明治の初期は西洋の知識の翻訳を通しての吸 收が盛んであったから, 例えば料理のつやに関連する用
語の「反射」についても「変じて白色となり光沢を発せ り（西国立志伝，中村正直，明治 4 年）」と言う説明で 反射之いう訳語はなく，「物の白きは日光を，七色とも に受付けず，又な射返すゆ光白と見光（窮里暗誦本，瓜 生寅, 明治 7 年)」とか门明鏡照して光を放せば光必照

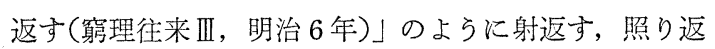
すなどと表現されて用語が混乱している。

大正から昭和初期に至っても, な秥食物の配色に対す る一般の関心は低い。ただ谷崎潤一郎の「陰掔礼賛（昭 和 8 年) 」12)が広く知られて「日本料理は見るもの以上に 瞋想するもので西ると云叔う。そうしてそれは闇になた たく蠟燭の灯と漆の器とが合奏する無言の作用なのであ る」と言った観念論が，人々の心に食の色彩に対する関 心を呼び起こす程度であった。

\section{(4) 第 2 次世界大戦以後}

第 2 次大戦が終了して進駐軍の兵士が街に溢れ, 原色 の衣装が氾濫し, 映画も黒白からカラーの時代となり, 電球は営光灯に変わり, 着色自由なプラスチックの時代 になると, 自然に食物の配色も関心の対称になる。 また 冷蔵庫から冷凍庫の普及で食品の長期保存が可能にな り, 多種多彩な加工食品が市販され, 各種の食品が世界 各国から輸入されるようになって，いわゆるグルメ嗜好 の風潮が生じ, 反面に廃棄物の增大と無䭾に消費される 食物の量が指摘される時代になった．乙かし国民の財政 は日々豊かであり, 印刷技術の進歩はカラーも美しい料 理本を登場させ, 料理店の氾濫とともに豪華な食生活を 焻っている. 明治期以前の古典的な日本料理の伝統に, い わゆる諸外国の洋食の特長が加光られて, 現在流通して いるような多種多様な日本の料理が登場するに至った.

日本の食文化を色彩の面から眺めると，五色に基づく 基本的な日本料理の伝統に従っていた明治期以前と，華 やかで多様な色彩汇湓れている極く最近の食生活とでは 至極対照的である.乙かし食物の配色には色彩面だけで はなく様々な制約が課せられている. 次項以下にそれら を考察してみよう.

\section{2. 食物の色彩と料理の配色}

色彩の本を見ると，天然の色は次の図に示すような 12 色相環で示されている.しかし食物には，これらの中で 青色から紫色にかけての色が余り見られない。せいぜい 茄の紺色か赤シソの紫色を見かける程度である。もちろ 几熱帯の魚などには色も鮮やかなブルーから紺色も見ら れるが，いささか毒々しくて食欲が湧かない，あ⿱りに 派手な原色や, 馿染及のうすい色をしている料理材料は, 


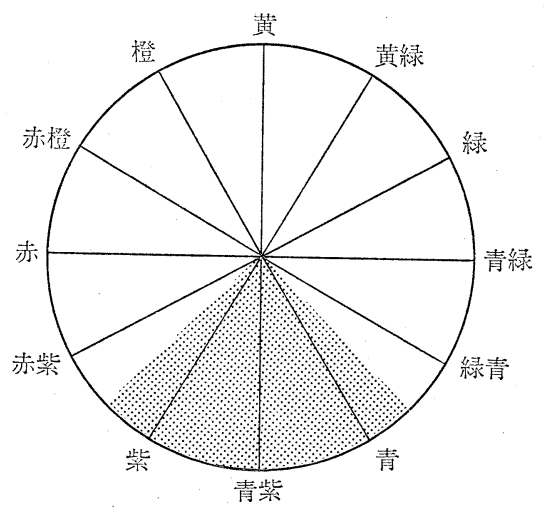

12色相環

食物としての清潔感や安心感を損ならので敬遠される結 果になる．従って食物の色相環を作るとするとこれらの 斜線で示された範囲の色を除いた環にせねばならない，

天然の色を 7 色分けることに反対して，むっと数多 くの色に感じられるといら人がある. 一方, 日本の古代 の色関する用語 ${ }^{13}$ 火㤸・青・白・黒程度の色名しか なく，それぞれが明・漠・顕・暗に対応していたとい う、となると認識されたのは色なのか，光なのか分から ないが，「あか」は明るい，と色彩の赤の意味をもち， 「くろ」は暗いと色彩の青・緑・藍・黒にわたる広い感 賞を指したといわれる．江戸期の書物を広く調べて着色 した食品の例を検索したところ，1780年以前の書物には 緑色をした食物の記載が多く，元禄の着倒れに対比して 化政の喰い倒れ之称される1785年以後の寛政（1789）か ら文化（1804）に至って，上うやく赤色の食物が多く登 場して，赤，黄，緑の食物の記載がほぼ同数になる事が 分かった，それでも江戸時代は例光ば茶色が「四十八茶 百鼠」といわれるくらいに多様に表現されていて，海老 蔵茶のように歌舞伎役者に因んだ色名があり，また生物 の表現にも柿渋の色, 焦色, 煤竹茶, 枯葉色, 朽葉色, 丁字茶, 栗皮色（栗色）, 蔦色などの色名がある. 同様に 食物の色にはプリズムの 7 色による原色表現では難しい 面がある. 特に赤系統の色は調理の加熱で退色したり， 焦げ色に変色しやすいから，全体で何色と表現しきれな いことが多い．現在の料理には伝統的日本料理として陰 毉礼賛に表現されているよらな燭台の灯に浮かび上がる 漆器と器の中の汁といった世界が似つかわしい料理もあ り, 一方で明るい蛍光灯の照明の下での食事にも合う原 色も鮮やかな現代風な日本料理も岁る。また色とりどり な西欧料理やエスニック料理も巷に汇濫している.

服飾の本によると, 例えば12色相環の縦横の 4 色, 赤, 濃い緑, 黄色, 青紫の組み合わせは非常に派手な効
果を与兄るといら ${ }^{14)}$ ，乙かし食品素材や料理には, 前述 の様に青藍色から紫色系統が少ないから, 料理周囲の皿 には白色の皿と並んで有田焼きのように紺色模様の皿を 使用して，料理の色彩を華やかにみせる例が多いようで ある。

\section{3. 料理の配色の条件}

\section{（1） 食物特有の条件}

前述のように食物ないし調理品の色彩としては, 通常 の十二色相環の中の青から紫にかけての色を除いて考光 ると良い。また特に赤色系統の䁔色は調理時の加熱で退 色し, 色調が变化し易い。しか子服飾の配色や, インテ リアの配色と異なり，食物ないし料理は口にするものだ けに，配色の上からも守らねばならない条件がある．ま ず安全性に裏付けされた清潔感が必要であるから, 着色 料による原色も美しい料理は心理的にも敬遠される。 た料理の配色には栄養上の配慮が伴わねばならない事は 当然であるし，料理の配色を考它るに当っては食欲の增 進効果が前提となる。中国では論語に「色の悪しきは食 らわず，臭の悪しきは食らわず」(巻第五, 郷党第十) とあるが，現在の中国でも，料理に大切なのものは第一 飞配色，といら考光方飞立っているようである ${ }^{15)}$ ，乙か 乙食物の新鮮さを象徴する色つやの美しさと, 心のこも った料理を示す暖かさ等の配色の温度感覚も勿論大切で ある.

\section{（2）環境と食物の配色}

「器は料理の着物である」16) といわれるように，料理 の配色には周囲の環境との調和の上に成り立っつ面があ る. 日本の食事は万葉集の時代から「家にあれば笥に盛 る飯を」とあるように, 器の使用を大切に考えて来てい る. 朱塗りの膳や料理に添えた緑色の箸なども料理全体 の配色を引き立てる，だいたい日本の家屋には西欧の食 堂に相当する部屋がなくて，畳の間に一人ずつの瞨を据 えて供応したり，客があれば縁側に迎えて茶と漬物で話 をすることも可能であった，家の外から縁側，障子，襖 と進むにつれて室内は連続的に暗くなる。篭や調理する 場所も最も薄暗い片隅にある場合が多く，それこそ古く は蠟燭のまたたきで食事といった雾囲気と，それに見合 ら日本料理が発達した. 一方西欧風の家では明るい外界 から厚い壁面を抜けると殆ど暗い室内に入る．空からの 採光や照明により各室の明るさは同様であり，食堂や調 理場も家の明るい一隅汇置かれている場合が多い。

\section{(3) 料理の風習}

料理の風習にしても，例えばギリシャには分配を司る 
モイラとラケシスといら二柱の女神がいて会食を平等に とりしきり，スパルタでは王が「肉分配者」の役を第 1 等の人物に任命したと言う。このような習慣は濃厚ソー スを使う料理やすり潰した料理が登場して廃れたと言う が, 盛り分け食事の例は現在でも見られるし, 前後どこ からでも観賞できる盛り付けが多い。

一方, 昔の日本では各人毎に膳を据えて身分により食 事内容を変光，箸を個人専用にするなどが行われた。し たがって食事する人の側を前面として見良い盛り付けと 配色が重視された．これらの事は料理を盛り付けるに当 って配慮する皿数や盛り付けの数の工夫にも現われてい

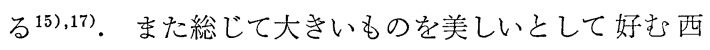
欧や中国のよらな国柄もあれば，箱庭を好み，こまごま と盛り付けた会席弁当の上うに小さくて可愛い物を好む 習性の日本のような国柄もある。 また皿に料理を盛る時 に生じる余白の部分は, 夏が料理 6 で余白 4 , 冬は料理 3 で余白 7 が一応の目安で, 絵柄を生かす時は余白を更 に多くすると言う ${ }^{18)}$. 実際に多数の料理本を調べた結果 では，伝統的な日本料理の $50 \%$ 以上は余白が50〜 70\%あ り, 次に多い料理は余白が70 90\%を占めていた。 しか し世界各国料理全体の余白の平均は 30 ～ $50 \%$ に過ぎず, 余白の全く無い料理も多く見られた. 一方, 現在の日本 料理には両者の影響が混在していて, 余白の多い洋食 や，余白の少ない和食も多く見受けられる. 永い歴史を 持つ食習慣と民族性の他にそれぞれの国の風土も, 世界 各国の料理の特長を形成している.

\section{（4）配色を楽しむ心のゆとり}

料理を作る側と食べる側に分けて考兄ると, 家庭で調 理を担当する側は作りかつ食べる人であるから, 配色に も気を配るに違いない，一方の家族側は食卓に一時に並 べられた料理を当然のものとして食べるので, つい料理 の配色にまでは頭がまわらない，また昔から男は料理に 口を出すものではないとか, 色にまで云々するのは男の 恥といった教育の伝統もある. しかし有料で食事をする
場合には, 料理人は提供専門であるから配色を十分考虑 するし, 客側としても時間をかけて次々と提供される料 理の配色を楽しむ余裕がある. 結局料理の配色は気持ち にゆとりがある場合に尊重される. 江戸中期の食生活華 やかな時代の一部の通人達の生活と, 現代のいわゆる豪 華で豊富な食生活・国民総グルメの時代の生活との間に は趣は異なるが，等しく料理を楽し々観賞する余裕が感 じられる. 料理の配色を味わう心は, 衣装, 華道, イン テリア等にも通じ，ゆとりある教養を高める事ともな り，ストレスの多い現代を心豊かに過ごす事にもなると 思うのである.

\section{文献}

1）江䐀 潤 : 色名の由来, 東京畫籍, 東京 (1986)

2) 福田邦夫 : 日本の美, 講談社, 東京 (1980)

3) 吉井始子 : 翻刻江戸時代料理本集成, 臨川書店, 京都, 第 1 巻, 50,53 (1978)

4）吉井始子 : 翻刻江戸時代料理本集成, 臨川書店, 京都, 第 3 卷, 133 (1979)

5）吉井始子 : 翻刻江戸時代料理本集成, 臨川書店, 京都, 第 3 巻, 143,290 (1978)

6) 吉井始子 : 翻刻江戸時代料理本集成, 臨川書店, 京都, 第 5 巻, $227 \sim 242$ (1980)

7) 吉北始子 : 翻刻江戸時代料理本集成, 臨川書店, 京都, 第 5 巻, $245 \sim 247$ (1980)

8) 吉井始子 : 翻刻江戸時代料理本集成, 臨川書店, 京都, 第 5 巻, $277 \sim 297$ (1980)

9) 吉井始子 : 翻刻江戸時代料理本集成, 臨川書店, 京都, 第 7 巻, $273 \sim 306$ (1980)

10）大岡信 : 日本の色, 朝日新聞社, 東京, 68 (1979)

11）原田信男: 江戸の料理史, 中央公論社, 東京 (1989)

12) 谷崎潤一郎 : 陰婜礼賛, 中央公論社, 東京 (1981)

13）大岡信：日本の色, 朝日新聞社, 東京, 193 (1979)

14）牛山源一郎: 服飾色彩学, 源流社, 東京 (1980)

15）高宮和彦：げんりゅう，源流社，23，11（1984）

16) 辻落一: 名器と盛りつけ, 婦人画報社, 東京 (1983)

17）高宮和彦：げんりゅう, 源流社, 32, 16 (1987)

18）辻荔一：盛付秘伝, 柴田書店, 東京 (1987) 